\title{
PERSONAL BRANDING RIA RICIS PADA MEDIA SOSIAL INSTAGRAM
}

\author{
Femilia Pertiwi $^{1}$, Irwansyah ${ }^{2}$ \\ Fakultas Ilmu Sosial Ilmu Politik, Jurusan Ilmu Komunikasi, Universitas Indonesia \\ Jl. Salemba Raya No 4, 10430, Jakarta Pusat, DKI Jakarta, 10440, Indonesia \\ No. Telp./HP: ${ }^{10} 085721673638$ \\ E-mail: ${ }^{1}$ femiliapertiwi.ui@gmail.com, ${ }^{2}$ dr.irwansyah.ma@gmail.com
}

Naskah diterima tanggal 29 April 2020, direvisi tanggal 21 Mei 2020, disetujui tanggal 14 September 2020

\section{RIA RICIS'S PERSONAL BRANDING ON SOCIAL MEDIA INSTAGRAM}

\begin{abstract}
The development of digital technology has made significant changes, including in the field of marketing. Digital media and the internet offer new ways of storing, informing, engaging, selling, learning and providing services to customers with new versions. Likewise, with one of the concepts in marketing communication that is personal branding. Personal branding is a planned process of people making an effort to market themselves by showing their competitive advantage. This process consists of the phase of building a brand identity, developing by communicating the brand and evaluating brand images to meet personal and professional goals. Then to make effectively and efficiently the formation of personal branding, it is necessary to involve digital marketing in social media platforms. This article discusses how to build correct personal branding on social media with a case study analysis of one of the people who succeeded in building her branding, Ria Ricis. The research method used is a qualitative method by conducting a combination of a literature meta-analysis and observation. The result showed that it is essential to plan personal branding and to utilize social media to build effective personal branding and to streamline business, and made it easier to reach a large number of audiences.
\end{abstract}

Keywords: personal branding, marketing communication, digital marketing, social media.

\begin{abstract}
Abstrak. Perkembangan teknologi digital telah membuat perubahan besar pada banyak bidang, termasuk bidang pemasaran. Media digital dan internet menawarkan cara penyimpanan baru, menginformasikan, melibatkan, menjual, mempelajari serta menyediakan layanan kepada pelanggan dengan versi yang baru. Begitupun dengan salah satu konsep dalam komunikasi pemasaran yaitu personal branding. Personal branding adalah proses terencana orang dalam upaya memasarkan diri dengan menunjukkan keunggulan kompetitifnya. Proses ini meliputi fase membangun identitas merek, mengembangkan dengan mengomunikasikan merek dan mengevaluasi merek gambar untuk memenuhi tujuan pribadi dan profesional. Kemudian untuk mengefektifkan dan mengefisiensikan pembentukan personal branding, perlu melibatkan pemasaran digital dalam platform media sosial. Artikel ini membahas bagaimana membangun personal branding yang benar pada media sosial dengan studi kasus analisis seseorang yang sukses dalam membangun personal branding-nya yaitu Ria Ricis. Metode penelitian yang digunakan adalah metode kualitatif dengan kombinasi meta-analisis literatur dan observasi. Hasil penelitian menunjukkan bahwa penting merencanakan personal branding dan media sosial dapat digunakan untuk membangun personal branding yang efektif yang mampu mengefisienkan usaha serta lebih mudah untuk menjangkau audiens dalam jumlah yang banyak.
\end{abstract}

Kata kunci: personal branding, komunikasi pemasaran, komunikasi digital, media sosial. 


\section{PENDAHULUAN}

Di era modern kehidupan bermasyarakat saat ini membuat setiap orang berorientasi pada jaminan. Kita menuntut pekerjaan yang dijamin, pendapatan, rezeki, asuransi, hubungan, jaminan pada mobil, peralatan rumah dan hampir semua hal. Merek (brand) menjawab kebutuhan ini dengan menyelubungi produk atau orang dengan ilusi jaminan. Merek menghilangkan persepsi risiko, menyiratkan bahwa ketika Anda membeli produk, dengan menggunakan orang tertentu yang menyelubungi produk maka pasti terjamin kualitasnya. Kekuatan brand menawarkan kepastian di dunia yang tidak pasti adalah salah satu pendorong fenomena personal branding (Montoya \& Vandehey, 2002).

Personal branding tidak hanya dimiliki oleh figur publik, selebritis atau orang terkenal lainnya. Setiap orang pada dasarnya sudah memiliki dan bisa membangun personal branding. Siapapun yang membangun karir dalam bidang profesi, industri atau keahlian kita masing-masing, personal branding sudah tumbuh seperti mutiara dalam tiram, dibangun dalam lapisan perilaku, perawatan orang lain, hasil pekerjaan, dan hal-hal yang sering dikatakan. Seiring waktu, perpaduan antara gambar, identitas, dan reputasi bergabung untuk menciptakan persepsi yang sederhana dan jelas tentang kita pada orang lain (Montoya \& Vandehey, 2002).

Masalah yang terjadi adalah sebagian besar orang membangun personal branding secara tidak sengaja. Banyak orang tidak sadar bahwa mereka sudah mengembangkan personal branding, tetapi tidak strategis sehingga mereka gagal memanfaatkan kekuatan brand mereka dan terus disabotase dengan kelemahan mereka. Hal tersebut terjadi berulang kali yang dipicu dari aktivitas dan perilaku yang tidak disadari dan intensif. Karena sejatinya brand yang ada pada tiap individu tumbuh dari kegiatan yang dilakukan berulang yang telah menjadikan kebiasaan dan melekat menjadi karakter seseorang.

Selain itu, perkembangan teknologi saat ini menyebabkan berkembang pula pola komunikasi masyarakat, terutama kemunculan media baru. Media baru ini muncul diawali dengan hadirnya internet. Media baru yang identik dengan teknologi digital inilah yang membuat banyak perubahan perilaku dan aktivitas manusia. Salah satu perubahan terbesar dalam interaksi manusia adalah perkembangan dari jejaring sosial. Pesatnya pertumbuhan platform berbasis web memfasilitasi perilaku daring sosial telah secara signifikan mengubah sifat, aktivitas manusia, habitat, dan interaksi (Tiago \& Veríssimo, 2014).

Penggunaan media digital membuat banyak orang yang mengakses media sosial melakukan interaksi. Interaksi dengan internet ini berlangsung sangat cepat. Jika tidak ada kesadaran personal branding seperti apa yang ingin diciptakan atau dibiarkan mengalir saja maka akan berdampak pada aktivitas pada jejaring sosial tersebut. Bisa saja kita tanpa sadar menunjukkan karakter negatif atau kelemahan yang terpublikasikan. Sebaliknya keunggulan-keunggulan bisa saja tidak terpublikasikan. Padahal pengaruh media sosial besar dan meluas sehingga akan berefek pada personal branding yang dilakukan. Jika kita salah dalam berinteraksi pada media sosial, bisa jadi personal branding yang tersebar di jejaring sosial tidak bagus, lemah, bahkan bisa menghancurkan reputasi diri sendiri. Contoh kegagalan personal branding yang terjadi adalah pada Briptu Norman (anggota Brimob Gorontalo) yang mendadak viral karena video amatir pada YouTube. Dalam video tersebut Briptu Norman terlihat sedang berjoget dan menyanyikan lagu 'Chaiyya-Chaiyya' secara lip sync menggunakan seragam polisi pada bulan April 2011. Rekaman video amatir tersebut telah disaksikan oleh 4,3 juta penonton. Tetapi ketenarannya tidak bertahan lama. Pada bulan Desember 2011 ketenarannya mulai meredup, bahkan kariernya di dunia kepolisian menjadi rusak. Setelah beralih ke dunia hiburan pun tidak mampu konsisten dan bersinar. Beralih pada pengusaha bubur manado pun tidak berhasil. Fenomena ini menunjukkan bahwa seringkali tidak disadari apa saja yang menjadi kelebihan dan kekurangan, serta apa saja yang akan ditonjolkan sebagai personal brand. 


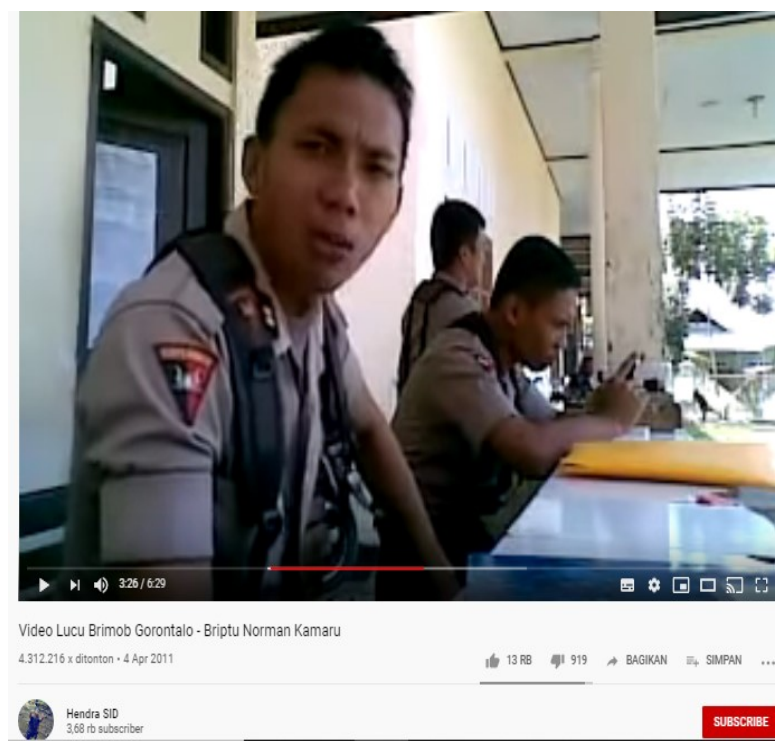

Sumber: Hendra SID, (2011)

Gambar 1. Video Lucu Brimob Gorontalo - Briptu Norman Kamaru

Seringkali malah kekurangan yang tersebar atau terjadi kontradiksi dengan aktivitas atau profesi keseharian, sehingga mudah berganti branding menunjukkan ketidakkonsistenan.

Media sosial telah meledak sebagai kategori wacana daring di mana orang yang membuat konten, berbagi, bookmark, dan jaringan pada tingkat luar biasa (Asur \& Huberman, 2010) misalnya Facebook, Instagram, Twitter, dan lain-lain. Hal ini dikarenakan media sosial memudahkan pengguna, menyajikan kecepatan, dan jangkauannya menciptakan interaksi baru manusia dengan orang yang tidak dikenal bahkan tidak pernah ditemui sebelumnya.
Berhenti jadi Polisi Pilih Jadi Artis

Kemudian Jualan Bubur Tak Disangka

Nasib Pria ini Sekarang

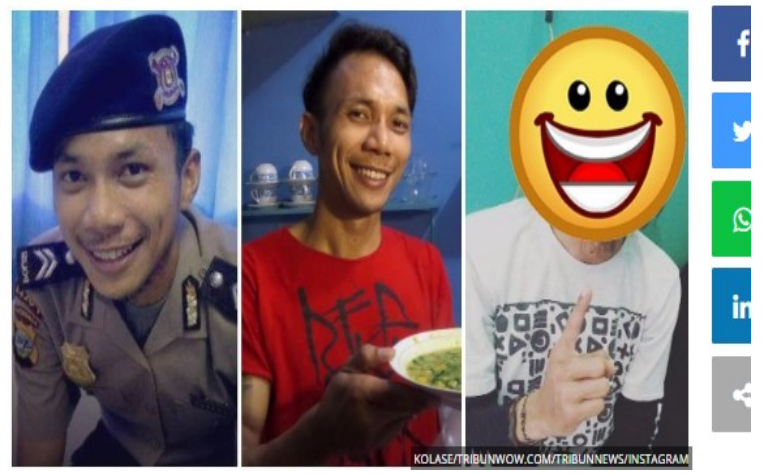

Sumber: TribunSumsel.com (2018)

Gambar 2. Perubahan Pekerjaan Norman

Media sosial sebagai sarana yang dipandang efektif dan efisien untuk melakukan aktivitas pemasaran. Dalam kasus media sosial, besar dan varians tinggi dari informasi yang disebarkan melalui komunitas pengguna menghadirkan peluang yang menarik untuk memanfaatkan data itu ke dalam bentuk yang memungkinkan prediksi spesifik tentang hasil tertentu, tanpa harus melembagakan mekanisme pasar (Asur \& Huberman, 2010). Bahkan mengumpulkan informasi tentang bagaimana orang berkomunikasi mengenai produk tertentu dapat membantu ketika merancang kampanye pemasaran dan periklanan (Asur \& Huberman, 2010).

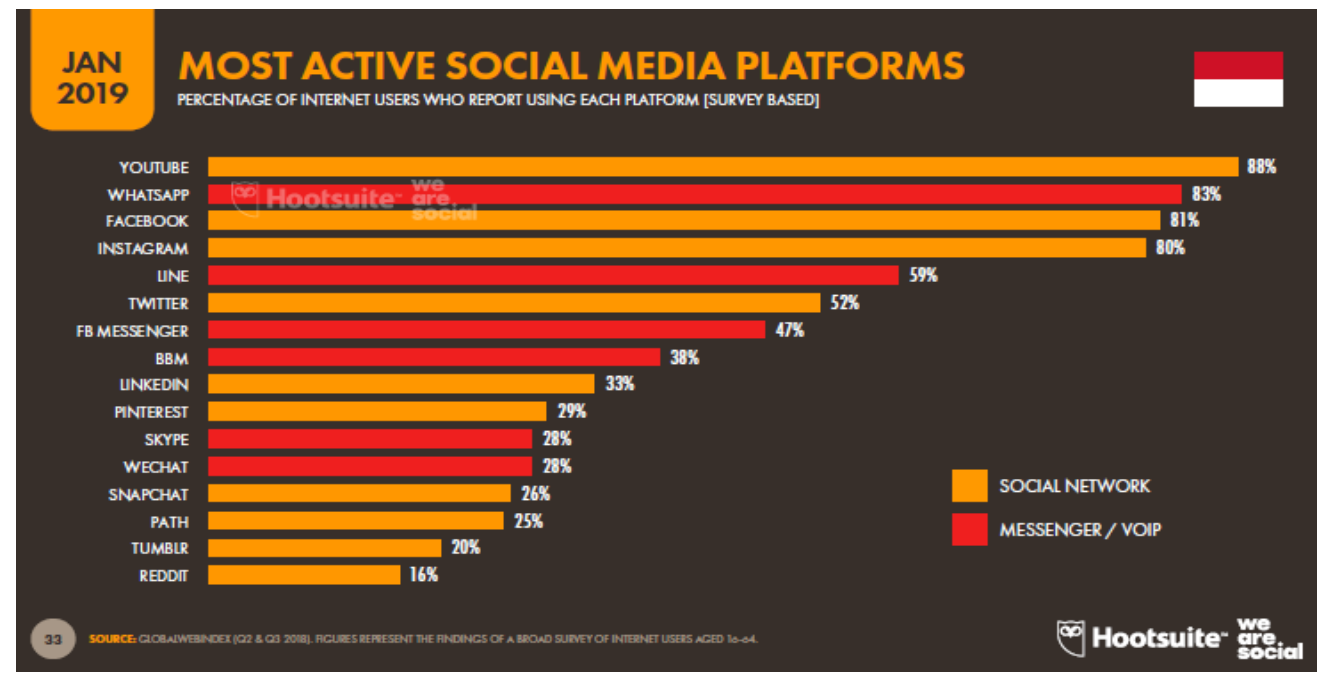

Sumber: Hootsuite (2019)

Gambar 3. Platform Media Sosial Paling Aktif 
Hasil riset dari We Are Social dan Hootsuite pada Januari 2019, pengguna media sosial di Indonesia mecapai 150 juta orang atau sebesar $56 \%$ dari total populasi. Sedangkan jumlah pengguna media media sosial dengan gawai meningkat sebesar 20\% dari survei sebelumnya, yaitu 130 juta atau 48\% dari populasi (Katadata.co.id, 2019). Penelitian yang dilakukan oleh We Are Social dan Hootsuite di tahun 2019 menunjukkan sepuluh platform aktif media sosial yang paling banyak digunakan oleh pengguna internet di Indonesia di antaranya YouTube (88\%), WhatsApp (83\%), Facebook $(81 \%)$, Instagram $(80 \%$, ) Line (59\%), Twitter (52\%), FB Messenger (47\%), BBM (38\%), LinkedIn (29\%), dan Pinterest (28\%).

Banyaknya pengguna media sosial dan aktivitas dalam media sosial yang terjadi di Indonesia menjadikan pentingnya seseorang melakukan personal branding dengan formula yang benar dan saluran media yang tepat. Hal ini agar tercermin keunggulan kompetitif melalui media baru yang bisa membantu proses tersebarnya informasi dengan cepat dan luas yakni dengan menggunakan media sosial Instagram dan YouTube yang merupakan salah satu media sosial dengan pengguna terbanyak yakni YouTube (88\%) dan Instagram (80\%) hasil riset We Are Social dan Hootsuite (Gambar $3)$.

Salah satu orang yang berhasil membangun personal branding dengan sukses adalah Ria Ricis. Personal branding yang telah dilakukan melalui media sosial Instagram dan YouTube membuatnya mendapatkan banyak peluang pekerjaan yang baru. Ria Ricis yang sebelumnya adalah seorang mahasiswi dan adik dari artis sekaligus ustadzah yaitu Oki Setiana Dewi kini telah berubah menjadi selebgram terkenal dan telah dicari untuk menjadi pembawa acara televisi, artis film layar lebar, dan lain-lain. Ria Ricis pertama kali membangun personal branding-nya melalui akun Instagram@riaricis1795. Mulai tahun 2015 hingga Juli 2019 akun ini telah mencapai 12,7 juta pengikut. Setahun setelah aktif pada Instagram, Ricis merambah ke YouTube. Ria Ricis pertama kali merilis video pertamanya pada 16 Maret 2016 dan kini sudah memiliki 15,9 juta subscriber (Setiawan, 2019).

Personal branding yang dibuat oleh Ria Ricis jauh berbeda dengan kakaknya, artis Oki Setiana Dewi yang jauh lebih dulu terkenal. Ria Ricis populer bukan karena 'panjat sosial' atau karena hubungan darah yang ia miliki dengan kakaknya, melainkan atas usahanya membangun personal branding yang tepat dengan cara yang tepat. Saluran media yang Ria Ricis gunakan, frekuensi, dan konten yang dipilih efektif dan efisien dalam membangun personal branding. Keberhasilan memiliki belasan juta pelanggan dan belasan juta pengikut Instagram dalam waktu empat tahun merupakan suatu kesuksesan. Jika dibandingkan dengan artis-artis yang lebih dulu terkenal di media tradisional seperti televisi, radio, bahkan layar lebar, Ria Ricis tergolong orang yang berhasil membangun personal branding dengan cepat.

Maka cara yang dilakukan Ria Ricis dalam membangun personal branding-nya pada media sosial Instagram menjadi suatu hal yang menarik untuk ditelaah. Rumusan masalah penelitian ini adalah bagaimana Ria Ricis membangun personal branding melalui media sosial Instagram? Tujuan penelitian adalah mengetahui langkahlangkah membangun personal branding melalui media sosial Instagram yang dilakukan oleh Ria Ricis. Manfaat penelitian ini secara akademis adalah mengetahui implementasi teori personal branding pada saluran komunikasi media baru yaitu Instagram.

\section{LANDASAN KONSEP}

\section{Komunikasi Pemasaran}

Komunikasi pemasaran adalah proses manajemen yang mana suatu organisasi mengikutsertakan audiensnya. Dengan memahami lingkungan komunikasi audiens, organisasi berusaha mengembangkan dan menyajikan pesan untuk mengidentifikasi kelompok mitra mereka, sebelum mengevaluasi dan menindaklanjuti tanggapan. Dengan menyampaikan pesan 
yang memiliki nilai signifikan yang mendorong audiens untuk menawarkan sikap dan respons perilaku (Fill, 2013).

Komunikasi pemasaran bermakna bagaimana konsep-konsep pemasaran ini mampu dikomunikasikan pada target audiens. Definisi komunikasi pemasaran memiliki tiga tema yaitu pertama, melibatkan (engage); dengan mengenali kebutuhan transaksional dan hubungan yang berbeda dari target audiens, komunikasi pemasaran dapat digunakan untuk melibatkan berbagai audiens sedemikian rupa sehingga komunikasi satu arah, dua arah, dan dialogis. Tema kedua menyangkut audiens untuk komunikasi pemasaran. Audiens adalah stakeholder yang memiliki koneksi dan hubungan dari berbagai dimensi. Sehingga komunikasi pemasaran harus didasarkan pada perilaku dan kebutuhan pemrosesan informasi serta gaya target audiens. Tema ketiga adalah respons kognitif yang merujuk pada hasil dari proses komunikasi yang merupakan ukuran apakah komunikasi berhasil. Sebagai contoh, merek dikembangkan untuk membantu konsumen dan membantu upaya pemasaran organisasi. Sebuah merek dapat menginformasikan kepada konsumen dengan cepat, misalnya "merek ini berarti kualitas x", dan melalui pengalaman pembelian merek yang serupa konsumen yakin bahwa risiko mereka diminimalkan.

Terdapat lima alat komunikasi pemasaran yang utama yaitu iklan, penjualan, promosi, hubungan masyarakat, pemasaran langsung dan penjualan pribadi (personal selling). Namun pada perkembangannya terdapat perubahan besar dalam lingkungan dan cara organisasi berkomunikasi dengan audiens target mereka. Teknologi baru telah memunculkan media yang berbeda, sementara orang telah mengembangkan berbagai cara untuk menghabiskan waktu luang mereka. Hal ini disebut fragmentasi media dan audiens dan organisasi telah mengembangkan kombinasi baru dari bauran promosi untuk mencapai khalayak mereka secara efektif. Misalnya peningkatan dramatis dalam penggunaan media respon langsung sebagai pemasaran langsung diadopsi sebagai bagian dari pemasaran.

\section{Digital Marketing}

Internet adalah saluran distribusi dan media komunikasi yang memungkinkan konsumen dan organisasi berkomunikasi dengan cara yang sangat berbeda. Ini memungkinkan interaktivitas dan mungkin merupakan media terbaik untuk mengaktifkan dialog. Komunikasi bersifat dua arah, interaktif dan sangat cepat, memungkinkan bisnis dan individu untuk menemukan informasi dan melakukan transaksi pertukaran (Fill, 2013).

Internet dan teknologi digital telah memungkinkan bentuk komunikasi interaktif baru, di mana penerima memiliki tanggung jawab yang lebih besar atas peran mereka dalam proses komunikasi. Internet adalah saluran distribusi dan media komunikasi itu memungkinkan konsumen dan organisasi untuk berkomunikasi secara radikal berbeda cara (Fill, 2013). Hal inilah yang disebut dengan digital marketing.

Digital marketing mengacu pada penggunaan media digital, teknologi dan data untuk menjangkau dan berinteraksi dengan audiens menggunakan perangkat dan platform digital yang berbeda, dikombinasikan dengan media tradisional untuk mencapai tujuan pemasaran (Chaffey \& Ellis-Chadwick, 2019). Terdapat beberapa elemen terpenting dari pemasaran digital di antaranya adalah online advertising, email marketing, social media, text messaging, affiliate marketing, Search Engine Optimization (SEO), dan Pay Per Click (PPC) (Yasmin, Tasneem \& Fatema, 2015).

\section{Personal Branding}

Brand (merek) adalah gagasan, persepsi, harapan, dan keyakinan yang ada di benak konsumen, pelanggan potensial, atau individu apapun yang dapat memengaruhi perusahaan (Kotler \& Pfoertsch, 2006). Merek dapat memberikan empat level makna (Kotler et al., 1999) yaitu: (1) Atribut, merek mengingatkan atribut produk tertentu. Misalnya, merek Mercedes menyarankan atribut seperti "direkayasa dengan baik", "dibangun 
dengan baik", "tahan lama", "prestise tinggi", "cepat", "mahal" dan "nilai jual kembali tinggi". Perusahaan dapat menggunakan satu atau lebih atribut dalam iklannya untuk mobil. Selama bertahuntahun, Mercedes mengiklankan "direkayasa tidak seperti mobil lain di dunia". Ini menyediakan platform penentuan posisi untuk atribut lain dari mobil.

(2) Manfaat, pelanggan tidak membeli atribut, mereka membeli manfaat. Karena itu atribut harus diterjemahkan ke dalam manfaat fungsional dan emosional. Misalnya, atribut "tahan lama" dapat diterjemahkan ke dalam manfaat fungsional, "Saya tidak perlu membeli mobil baru setiap beberapa tahun". Atribut "mahal" dapat diterjemahkan menjadi manfaat emosional, "Mobil membuat saya merasa penting dan dikagumi". Atribut "dibangun dengan baik" dapat diterjemahkan menjadi manfaat fungsional dan emosional, "Saya aman jika terjadi kecelakaan."

(3) Nilai, merek juga menyampaikan sesuatu tentang nilai-nilai pembeli. Dengan demikian pembeli Mercedes menghargai kinerja tinggi, keamanan dan prestise. Pemasar merek harus mengidentifikasi kelompok pembeli mobil tertentu yang nilainya sesuai dengan paket manfaat yang dikirimkan.

(4) Kepribadian, merek juga memproyeksikan kepribadian. Peneliti kadang bertanya, "Jika merek ini adalah seseorang, orang macam apa?" Konsumen mungkin memvisualisasikan mobil Mercedes sebagai eksekutif bisnis paruh baya yang kaya. Merek akan menarik orangorang dengan citra diri aktual atau yang diinginkan cocok dengan citra merek.

Merek tidak hanya dipakai untuk menandai produk barang maupun jasa melainkan juga untuk orang atau organisasi. Misalnya untuk selebritis, artis, figur publik bahkan untuk seseorang yang hendak membangun karier. Merek yang dimiliki oleh individu inilah yang disebut personal branding. Dengan membangun nama, prestasi, dan reputasi pada dasarnya seseorang sedang menciptakan personal branding.
Personal branding yang hebat membutuhkan keaslian mutlak, termasuk kemampuan untuk mengakui kelemahan di depan umum. Sayangnya, terlalu banyak orang yang mencoba menyembunyikan kekurangan mereka atau yang lebih buruk, sebaliknya memaksakan melakukan serangan, penolakan atau pengingkaran pada kelemahan tersebut, bukan berfokus pada pengembangan keunggulan mereka. Personal branding menuntut agar setiap praktisi dipersiapkan untuk evaluasi diri yang menantang dan jujur (Montoya \& Vandehey, 2002).

Dalam personal branding terdapat tiga elemen pembentuk, yaitu penampilan, kepribadian, dan karakter. Personal branding bekerja dengan cara yang sama megomunikasikan nilai, kepribadian, dan gagasan tentang kemampuan kepada audiensnya untuk menghasilkan respons, kemudian memperkuat respons itu dengan lebih banyak kontak.

Personal branding yang kuat memiliki ciri-ciri: (1) Khas, artinya personal brand mengandung sesuatu yang menjadi keyakinan, nilai-nilai dan prinsip, termasuk hal yang diminati. Sehingga ada tekad yang kuat atas nilai dan keyakinan tersebut. Hal ini dikarenakan nilai-nilai akan memengaruhi apa yang dipikirkan, dirasakan, dan perilaku seseorang. Semakin khas (berbeda) tindakan yang dilihat audiens maka semakin tegas dan jelas definisi personal branding seseorang bagi audiens.

(2) Relevan, artinya personal brand yang kuat tidak hanya khas melainkan harus memiliki hubungan yang dianggap penting oleh audiens. Dengan kata lain yang diperjuangkan harus relevan bagi audiens. Relevansi adalah sesuatu yang dihasilkan dari kepentingan orang lain apa yang dilakukan untuk mereka dan dengan penilaian mereka tentang seberapa baik seseorang melakukannya. Relevansi bagian dari proses yang diawali oleh pertanyaan berikut: a) Apa yang audiens inginkan? b) Apa yang audiens perlukan? c) Apa yang audiens hargai? d) Apa yang audiens harapkan?

(3) Konsisten, artinya hal-hal yang khas dan relevan tadi dilakukan secara 
berulang atau direpetisi. Hal ini dikarenakan orang baru akan percaya pada suatu hubungan berdasarkan pada konsistensi perilaku yang mereka alami atau amati. Konsistensi adalah ciri khas dari semua merek yang kuat. Sebagai 'merek', seseorang hanya mendapatkan 'kredit' (pengakuan, penerimaan, atau pengakuan oleh orang lain) dari apa yang dilakukan secara konsisten. Perilaku konsisten mendefinisikan merek seseorang lebih jelas terbukti. Relevansi setiap figur publik dengan kebutuhan dan nilai seseorang juga akan bervariasi. Tapi suka atau tidak suka, butuh atau tidak, seseorang merasa tahu harus ke mana harapan dari orang-orang ini karena perilaku mereka sangat konsisten selama bertahun-tahun (McNally \& Speak, 2010).

Cara mengembangkan personal branding (Labrecque, Markos \& Milne, 2011) yaitu: (1) Membangun identitas merek (brand identity). Dalam konteks daring, identitas personal branding bergantung pada penyajian diri saat identitas dibuat dalam komputer menggunakan profil jejaring sosial, blog atau halaman web pribadi. Identitas bisa berupa status yang melekat dan kepribadian.

(2) Mengembangkan posisi merek (brand positioning). Brand positioning mengacu pada komunikasi aktif identitas merek seseorang ke target pasar yang spesifik. Penggunaan brand positioning untuk menyoroti atribut positif mereka dalam menghargai target audiens mereka, sementara pada saat yang sama membedakan diri dari individu lain dalam pasar. Untuk personal branding daring, brand positioning terjadi melalui manajemen kesan. Dalam konteks daring, ini dilakukan dengan mempertahankan citra yang konsisten melalui pilihan untuk mengungkapkan informasi pribadi melalui blog dan pengungkapan di situs-situs seperti jaringan sosial. Tantangan utama bagi peserta, diputuskan informasi apa yang akan dikirim secara daring, setelah menyaring informasi yang tidak selaras dengan strategi branding mereka. Selain informasi demografis, profil termasuk juga informasi seperti daftar buku favorit, musik, kutipan, dan film, serta foto.

(3) Penilaian citra merek (brand image). Citra merek tergantung pada informasi yang diunggah yang bergantung pada informasi yang diunggah orang lain dan reaksi pasar terhadap informasi yang disajikan yang umumnya berdasarkan perilaku yang terlihat, perilaku nonverbal dan isyarat yang dapat diamati lainnya. Kunci dari pembangunan citra merek adalah repetisi hingga terjadilah konsistensi.

\section{Media Sosial}

Media sosial adalah satu frasa yang menggabungkan dua kata familier yaitu media dan sosial. Sosial istilah kata yang sering disandingkan manusia sebagai makhluk sosial artinya mengandalkan kemampuan seseorang berinteraksi dengan dan memengaruhi orang lain untuk bertahan. Sedangkan media secara tradisional, media mencakup hal-hal seperti koran, majalah, dan televisi. Sementara kata media memang menyulap gambar berita organisasi, itu juga memunculkan kesan tentang bagaimana berita disampaikan: via cetak, audio, video, dan foto. Masing-masing adalah media yang penting dulu melibatkan audiensi dengan menceritakan kisah yang menarik atau berbagi berita penting. Media selalu pandai mengumpulkan orang untuk membaca, menonton, atau mendengarkan sesuatu yang menarik kata-kata, gambar, video, dan audio dapat memberi informasi dan inspirasi, sama seperti mereka dapat memengaruhi dan menghasut. Manusia ingin tahu tentang yang baik, yang buruk, dan sisi buruk orang, tempat, dan situasi, serta untuk membagikan ini informasi dengan orang lain, sesering mungkin. Sehingga definisi media sosial mengacu pada kegiatan, praktik, dan perilaku di antara komunitas orang yang berkumpul secara daring untuk berbagi informasi, pengetahuan, dan opini menggunakan media percakapan. Media percakapan berbasis web aplikasi yang memungkinkan untuk membuat dan mengirimkan konten dengan mudah di internet bentuk kata-kata, gambar, video, dan audio (Safko \& Brake, 2009). 
Ada sekitar 15 kategori alat serta contoh aplikasi yang bisa mendeskripsikan fungsi media sosial (Safko \& Brake, 2009):

1. Social Networking (Jejaring Sosial)

Jejaring sosial adalah aktivitas manusia (interaksi komunikasi) dalam bentuk teknologi digital. Alat jejaring sosial memungkinkan seseorang untuk berbagi informasi tentang diri dan minat kepada teman, kolega, dan audiens dalam media sosial.

Instagram merupakan media sosial yang mempunyai jaringan sosial yang luas. Instagram pertama kali berdiri tahun 2010 oleh perusahaan Burbn, Inc dengan Kevin Systrom dan Mike Kriegeryang sebagai CEO. Instagram berfokus pada aktivitas berbagi foto, komentar, like untuk setiap foto yang diunggah. Dalam perkembangannya tidak hanya foto melainkan juga video pendek dengan durasi maksimal 15 detik dan diperbarui lagi awal tahun 2016 dengan durasi maksimal 60 detik. Semakin banyak like yang didapatkan maka sebuah unggahan semakin populer dan itu memberikan pengaruh pula pada jumlah follower akun tersebut.

\section{Publish}

Mencakup alat yang memfasilitasi $e$ mail, kampanye, blog, dan wiki. Bahkan alat yang membantu mengelola semua jenis konten daring. Pada media sosial yang dapat menarik audiens adalah konten yang tepat dan atraktif.

\section{Photo Sharing (Berbagi Foto)}

Kemampuan untuk mengarsipkan dan berbagi foto untuk berkomunikasi, berkolaborasi dan mendidik mewujudkan efisiensi dan keuntungan besar. Kemampuan membagikan foto yang menarik dan merupakan kekuatan dari personal branding akan menguatkan branding. Contohnya aplikasi berbagi foto yaitu Pinterest dan Instagram.

4. Audio

Kemampuan mengunduh ribuan jam lagu bisa menjadi keunggulan dibandingkan alat berbasis teks bahkan video, karena menyajikan sesuatu yang bisa didengar, sehingga manusia bisa mendengarkan sambil beraktivitas. Contoh media sosial audio adalah iTunes, podcast.

\section{Video}

Kemampuan video di ponsel dapat membantu mengabadikan dan berbagi momen. Hiburan audio dan visual menjadi hal yang menarik bagi audiens yang membutuhkan hiburan. Contohnya Google Video, Viddler, YouTube.

\section{Microblogging}

Microblogging adalah persilangan antara blogging dan pesan teks. Biasanya jika seseorang ingin berkomunikasi dalam bentuk teks dengan batasan 140 karakter setiap unggahan. Contoh aplikasi microblogging yaitu Plurk, Twitter.

7. Livecasting

Livecasting adalah kategori media sosial yang memungkinkan untuk menyiarkan video langsung dan siaran audio ke jaringan. Kategori ini mencakup radio internet dan aplikasi lain yang memungkinkan seseorang mengalirkan siaran langsung ke audiens atau jejaring sosial. Contohnya BlogTalkRadio, Live 365, JustinTV, SHOUTcast.

\section{Virtual Worlds}

Virtual Worlds menghadirkan batas baru untuk bisnis dengan kemungkinan interaksi real-time dengan karyawan, pelanggan, dan vendor. Contohnya Active Worlds, Kaneva, Second Life.

\section{Gaming}

Game daring adalah magnet yang menarik banyak orang dengan minat yang sama. Gamer mewakili jenis khusus jejaring sosial. Contohnya Entropia Universe, EverQuest, World of Warcraft.

\section{Productivity Application}

Aplikasi produktivitas adalah perangkat lunak atau aplikasi yang digunakan untuk menghasilkan informasi dan meningkatkan produktivitas bisnis dan pribadi (seperti dokumen, presentasi, lembar kerja, basis data, bagan, grafik, lukisan digital, musik elektronik, dan video digital). Contohnya Google Docs, Google Gmail, Yahoo!, AOL, Survey Monkey, TiddlyWiki, dan Zoomerang.

\section{Aggregator}

Aggregator adalah mesin peneliti, pengumpulan informasi, atau staf riset digital. Contohnya Digg, iGoogle, My Yahoo!, Google Reader, dan Yelp. 


\section{RSS}

RSS singkatan dari Rich Site Summary. Teknologi ini digunakan secara luas oleh komunitas weblog untuk menyebar ringkasan tulisan terbaru jurnal, terkadang juga menyertakan artikel lengkap gambar dan suara. Contohnya Atom, FeedBurner, PingShot, RSS 2.0

13. Search

Alat pencarian contohnya Google Search, Meta Tube, Yahoo! Search, EveryZing, IceRocket, Redlasso dan Technorati.

\section{Mobile}

Aplikasi mobile adalah aplikasi yang memungkinkan seseorang melakukan mobilitas, hal ini dikarenakan benda berteknologi tersebut dapat bergerak tanpa menggunakan kabel, sehingga memudahkan pergerakan penggunanya. Contohnya adalah airG, AOL Mobile, Brightkite, CallWave, Jott, Jumbuck, dan SMS.ac.

\section{Interpersonal}

Interpersonal maknanya adalah alat yang memfasilitasi komunikasi dan kolaborasi antarorang. Contohnya adalah aplikasi Acrobat Connect, AOL Instant Messenger, Go To Meeting, iChat, Jott, Meebo, Skype, dan WebEx.

\section{METODE PENELITAN}

Penelitian ini menggunakan pendekatan kualitatif yang bertujuan untuk mengeksplorasi secara mendalam sebuah fenomena. Penelitian kualitatif adalah aktivitas penelitian dengan menempatkan peneliti di dalam tempat dilakukannya penelitian tersebut (Denzin \& Lincoln, 2011). Penelitian kualitatif ini berisi tinjauan literatur, konsep-konsep teoritis yang berhubungan dengan masalah penelitian yakni masalah personal branding dan penggunaan media sosial dalam membangun personal branding kemudian dilanjutkan dengan observasi dan analisis wacana. Tinjauan literatur khususnya dengan metaanalisis literatur yaitu teknik khusus yang digunakan untuk membuat tinjauan integratif atau tinjauan metodologi. Metaanalisis melibatkan pengumpulan rincian mengenai berbagai penelitian sebelumnya dan menyatukan hasilnya dalam empat langkah (Neuman, 2017) yaitu : (1) Mencari semua penelitian potensial pada suatu topik atau pernyataan penelitian tertentu; (2) Mengembangkan kriteria yang konsisten dan studi layar untuk relevansi dan menyaring penelitian untuk memperoleh relevansi dan/ kualitas; (3) Mengidentifikasi dan mencatat informasi menjadi temuan yang luas; (4) Menarik kesimpulan berdasarkan temuan tersebut.

Selain meta-analisis, metode pengambilan data yang digunakan adalah observasi dan analisis wacana (akun Instagram@riaricis1795). Peneliti memilih akun Ria Ricis sebagai telaah personal branding yang dibangun melalui Instagram karena pada awalnya Ria Ricis adalah influencer Instagram yang kemudian menjadi terkenal hingga merambah ke kanal YouTube dan dikenal sebagai ratu YouTube dengan peringkat kedua dengan jumlah subscriber terbanyak di Indonesia. Berikut penjelasan langkah-langkah tersebut.

(1) Mengidentifikasi Artikel yang Relevan

Pertama dimulai tentang topik terkait komunikasi pemasaran, kemudian digital marketing, personal branding dan media sosial dengan mempertimbangkan artikel yang diterbitkan pada periode 2000 s.d. 2019 sebagai teori yang terbaru dan mutakhir. Peneliti mencari jurnal dan buku dalam pencarian internet untuk memahami definisi dari komunikasi pemasaran, digital marketing, personal branding, dan media sosial. Artikel-artikel yang diprioritaskan adalah yang terbit pada tahun 2000 s.d. 2019. Selanjutnya peneliti memeriksa artikel-artikel tersebut sebagai referensi untuk mengidentifikasi artikel relevan lainnya yang diterbitkan dalam jurnal ini selama jangka waktu yang sama. Setelah itu peneliti melanjutkan prosedur bola salju dengan mencari perluasan kata kunci istilah yang lebih spesifik (misalnya: personal branding daring, personal branding instagram, personal branding social media). Peneliti mengulangi proses meninjau daftar referensi untuk mengidentifikasi artikel tambahan untuk dimasukkan. Secara keseluruhan, puluhan artikel dalam jurnal 
maupun buku marketing khususnya personal branding dan media sosial yang bersifat teoretis dan subtantif.
(2) Mengklasifikasi Artikel dan
Pengumpulan Data

Dari artikel yang telah terkumpul dari setiap artikel peneliti juga mengumpulkan kata kunci yang diterbitkan dari daftar isi untuk buku atau kata kunci untuk setiap jurnal. Mengumpulkan data berdasarkan klasifikasi kata kunci yang sudah diurutkan. Peneliti menyusun kumpulan data berdasarkan kata kunci sesuai dengan sistematika menjawab masalah dalam penelitian ini.

\section{(3) Melakukan Observasi}

Observasi yang dilakukan adalah selama empat minggu yaitu dari tanggal 14 Februari hingga 14 Maret 2019 dengan cara mengamati aktivitas unggahan gambar maupun video Ria Ricis, mencermati seberapa intensif unggahan tersebut dan apa saja jenis konten yang dibagikan.

(4) Analisis Wacana

Dari data observasi yang ditemukan, peneliti menganalisis apakah konten yang dibagikan sudah secara konsisten mencerminkan personal branding yang dibangun dan apa efeknya terhadap engagement rate terhadap netizen.

Seluruh konsep membangun personal branding dijadikan pisau analisis data yang didapatkan dari hasil observasi dan literatur terdahulu, kemudian peneliti menarik simpulan.

\section{HASIL PENELITIAN DAN PEMBAHASAN}

\section{Personal Branding Ria Ricis}

Meski Ria Ricis posisinya berada di peringkat kedua, Ria Ricis tetap dikenal sebagai ratu YouTube (Munzi, 2019). Pada awalnya Ria Ricis memiliki tujuan untuk menghibur audiens dengan konten meme dan parodi yang diunggah pada Instagram. Kemudian apa yang diunggah mendapatkan banyak like hingga followers akun
Instagramnya menjadi jutaan orang. Dari Instagram Ria merambah ke YouTube hingga mencapai jumlah pelanggan (subscribers) yang fenomenal. Dari Instagram dan YouTube Ricis semakin dikenal hingga mulai ditawari untuk mengisi acara TV hingga menjadi aktris film.

Peneliti menganalisis personal branding yang dibangun Ria Ricis dengan mengamati media sosial yang digunakan Ria Ricis sebagai saluran media dalam mengkomunikasikan personal brandingnya. Pada tahun 2015 Ria Ricis pertama kali menggunakan Instagram sebagai media sosial yang dipilih untuk menyebarkan konten yang mencerminkan personal branding-nya. Jenis media sosial yang dipilih adalah Instagram dengan kategori jejaring sosial yang memungkinkan adanya interaksi bersifat dua arah, dari dirinya dan dari audiens media sosial.

Hal ini sesuai dengan konsep komunikasi pemasaran yakni pelibatan (engagement) antara pemilik akun dengan audiens. Ria Ricis menginginkan adanya pelibatan yang intens dan erat antara dirinya dengan audiens. Jenis konten yang diterbitkan adalah teks, video pendek, dan foto.

Selama proses observasi dari 14 Februari hingga 14 Maret (28 hari) diketahui unggahan foto dan video Ria Ricis berjumlah 36 unggahan. Ini berarti dalam sehari Ria Ricis konsisten membagikan konten dalam bentuk foto, video maupun caption sebanyak 1-2 kali dalam sehari.

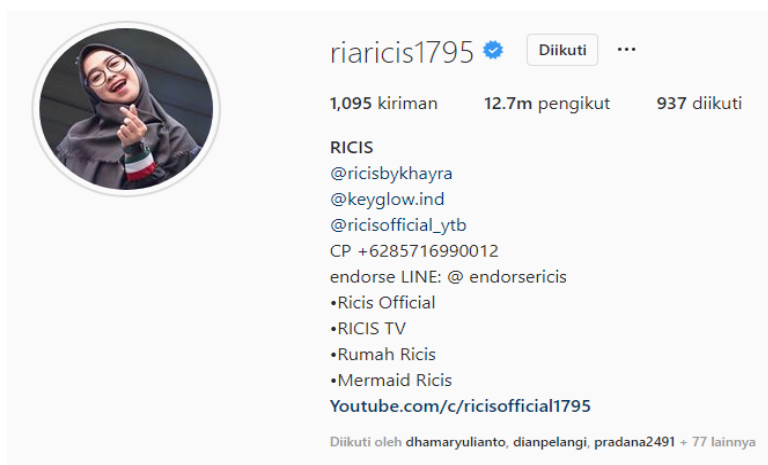

Sumber: Instagram Riaricis1795 (2019). Gambar 4. Akun Instagram Ria Ricis 


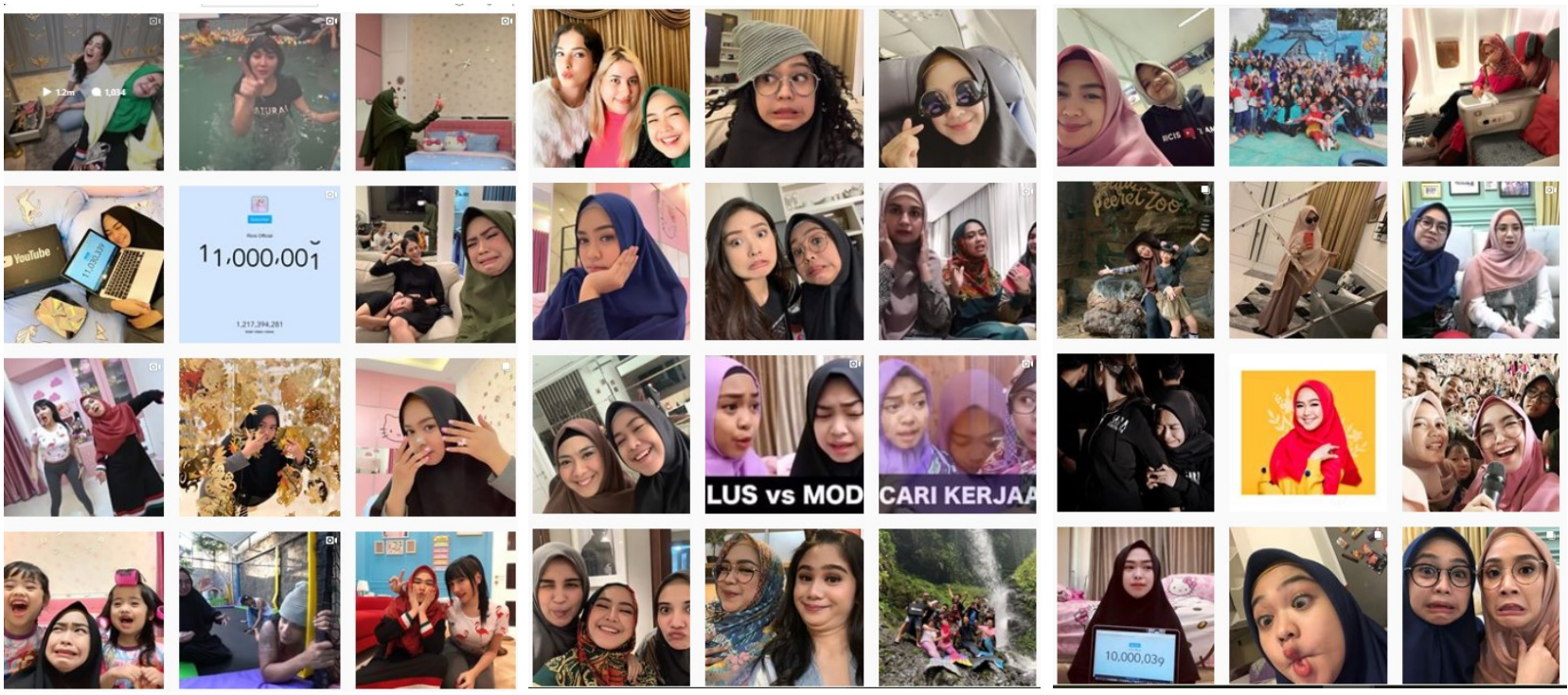

Sumber: Instagram Riaricis1795 (2019).

Gambar 5. Akun Instagram Ria Ricis 14 Februari-14 Maret 2019

Jenis-jenis unggahan foto, video, dan caption jenis pertama adalah foto wajah berkerudung menutupi dada, dengan pakaian yang berwarna dominan cerah dengan ekspresi monyong atau "memble", menggunakan wig dan topi, yang sangat identik dengan muslimah yang ceria, riang, kocak atau humor. Ekspresi ini sangat berbeda dengan kebanyakan artis wanita yang membagikan foto cantik, jaim (jaga image) atau pose anggun. Jenis foto ini menunjukkan personal branding yang ingin ditunjukkan oleh Ria Ricis telah menunjukkan diferensiasi atau kekhasan dengan artis/selebgram/influencer lainnya. Sebut saja beberapa artis wanita muslimah seperti kakaknya sendiri Oki Setiana Dewi, Shireen Sungkar, Zaskia Sungkar, Laudya Chyntia Bella, Zaskia Adya Mecca yang cenderung menampilkan wajah kalem, manis, cantik dan anggun. Ria Ricis justru hadir dengan wajahnya yang dibuat sangat berbeda dari kebanyakan artis wanita yaitu wajah yang dibuat jelek dengan monyong, tingkah laku yang kocak, sangat enerjik dan humoris.

Jenis kedua adalah foto bersama remaja-remaja atau milenial atau foto bersama kru tim kreatif Ria Ricis yang didominasi anak remaja (milenial), personal branding yang ingin ditunjukkan oleh Ria Ricis adalah remaja/milenial. Jenis ketiga adalah video Ria Ricis memerankan berbagai macam karakter remaja dalam satu tema, dengan tema-tema remaja seperti "tulus vs modus", konten yang dibuat oleh Ricis berhubungan sangat dekat atau relevan dengan audiens. Ria Ricis mengangkat masalah-masalah yang dialami oleh target audiensnya yang didominasi remaja dan dewasa muda. Misalnya saja tentang kelulusan, cari kerja, "tulus vs modus", dance, dan lain-lain.

Jenis keempat adalah kolaborasi dengan sesama selebritis/selebgram remaja atau muda yang sedang terkenal atau viral seperti Tasya Farasya, Lucinta Luna, atau Nagita Slavina. Personal branding yang keempat menunjukkan ketenarannya setara dengan artis remaja atau artis muda yang kekinian atau gaul. Jenis konten kelima adalah tarian/goyangan dan nyanyian serta semua yang terlihat ceria. Hal itu menunjukkan bahwa personal branding yang ingin ditampilkan adalah kebahagiaan, keceriaan, dan sangat menghibur.

Personal branding Ria Ricis adalah remaja muslimah, kocak atau humoris dan kekinian/gaul. Jika dianalisis melalui teori personal branding yang kuat ketiga nilai personal branding yang dibangun oleh Ria Ricis sudah memenuhi ciri personal branding yang kuat yaitu khas, relevan dan konsisten. Dari aspek kekhasan Ria Ricis berusaha menampilkan suasana yang berbeda yakni remaja wanita muslimah yang identik dengan kalem, baik, lembut, pendiam diubah menjadi remaja muslimah 
yang aktif, enerjik, ceria, humoris atau kocak. Hal ini tentu menjadi diferensiasi yang cukup bisa ditonjolkan sehingga menjadi ciri khas keunikan yang dimiliki Ria Ricis yang berbeda dari yang lain. Termasuk sangat berbeda dengan kakaknya yaitu Oki Setiana Dewi yang lebih menunjukkan sikap sopan, santun, kalem, lembut, berkerudung lebar dan lebih dewasa. Pada aspek relevansi nilai muslimah kocak, humoris, dan kekinian/gaul mampu diterima dan merupakan kebutuhan dari penonton yang ditargetkan oleh Ria Ricis. Dari segi konsistensi Ria Ricis konsisten membawakan konten-konten problematika remaja yang menarik, menghibur, dan humoris. Dan ia melakukannya secara berkelanjutan konsisten minimal 1-2 konten perhari.

Pada media sosial Instagram yang digunakan oleh Ria Ricis ia mengoptimalkan fungsi-fungsi media sosial yaitu jejaring sosial yakni interaksi Ria Ricis dengan para netizen lewat IG story, berbagi foto-foto yang mencerminkan personal branding, video, dan lain-lain.

Langkah-langkah yang dibangun oleh Ria Ricis dalam membangun personal brandingnya memenuhi kaidah personal branding yang khas, relevan dan konsisten dengan cara:

(1) Pemetaan diri sendiri, Ria Ricis sudah tepat dan mampu memetakan kekuatan dan kelemahan dirinya. Ria Ricis menyadari bahwa kepribadiannya jauh berbeda dengan kedua kakaknya yaitu Oki
Setiana Dewi maupun Shindy Kurnia Putri yang kalem, lemah lembut, dan anggun. Ria Ricis menyadari perbedaan tersebut yang telah sering pula diungkap media bahwa Ria Ricis berbeda secara kepribadian, meski kakaknya terlebih dahulu menjadi selebritis tetapi Ria Ricis tidak tertarik membangun personal branding yang sama dengan kakaknya.

Ria Ricis memetakan hal-hal apa saja yang sangat diminati, nilai-nilai yang hendak diperjuangkan, karakteristik atau kepribadian serta keunggulan kompetitif yang mampu menjadi kekhasannya. Tujuan menemukan nilai adalah sebagai fondasi dalam membangun brand identity (identitas merk). Karena personal branding yang benar harus asli yang mencerminkan diri seseorang, bukan sesuatu yang dibuat-buat atau palsu (bertentangan dengan kenyataan).

Kemudian memetakan keunggulan kompetitif seseorang tujuannya untuk membangun brand positioning yang menjadikan seseorang berbeda dengan lainnya, yang menjadi kekhasan bahwa seseorang unggul di sana dibandingkan kebanyakan orang lain. Di sini Ria Ricis telah menunjukkan perbedaan dia dengan kebanyakan selebgram/artis/influencer wanita lainnya yang didominasi menampilkan wajah yang terbaik yang manis, yang cantik, yang kalem, dan anggun. Di sini sangat berbeda dengan apa yang ditampilkan Ricis yang berani menampilkan wajah yang dibuat jelek dengan ekspresi-ekspresi monyong, sangat

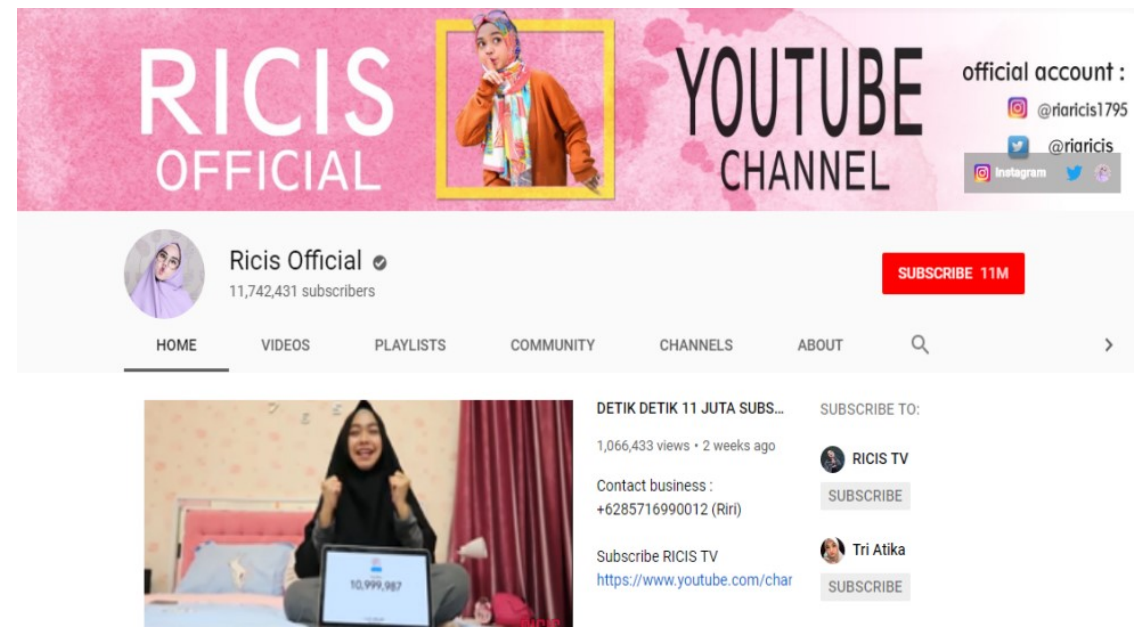

Sumber: Ricis Official YouTube Channel (2019). 
percaya diri, enerjik, dan kocak. Hal ini menjadi daya positioning yang jelas akan kekhasan Ricis.

Ria Ricis memetakan dirinya sebagai seorang muslim yang taat agama dengan menggunakan jilbab sesuai kepercayaan yang diyakini, artinya tidak ada yang diubah atau personal branding-nya linier dengan keyakinannya. Selain jilbab yang dikenakan mencerminkan keyakinannya sebagai muslimah, efek samping dari penggunaan jilbab adalah identik dengan lembut, kalem, dan anggun. Tetapi Ria Ricis pun memetakan dirinya yang memiliki kepribadian jauh dari kalem, lembut, justru Ria Ricis orang yang aktif, kocak, dan sangat enerjik maka personal branding yang ditampilkan justru hal yang berbeda dari yang umum.

(2) Menetapkan target audiens, penting untuk memetakan target audiens yang seperti apa yang hendak dijawab kebutuhan, keinginan, dan harapannya. Hal ini dikarenakan syarat personal branding yang kuat adalah yang memiliki relevansi dengan audiens. Tidak cukup hanya memperhatikan sesuatu yang khas dari seseorang jika audiens merasa itu tidak penting baginya. Di sisi lain audiens sangat heterogen dari segi usia, pekerjaan, sedangkan seseorang memiliki kapasitas dalam memenuhi itu semua. Oleh karena itu penting bagi seseorang untuk melakukan segmentasi (pengelompokan) audiens hingga penyusunan target yang paling realistis untuk dipenuhi dan jika secara jumlah banyak maka semakin besar pula personal branding yang akan terbentuk, kemudian menetapkan tujuan dari pembangunan personal branding.

Ria Ricis memandang bahwa Ria Ricis memiliki kesamaan status sebagai milenial tentu hal ini bisa menjadi kemudahan untuk menargetkan audiens dengan usia yang tidak jauh dari usianya. Menurut Databoks.co.id, secara skala target segmen Ria Ricis adalah generasi muda atau milenial dengan rentang usia 15 s.d. 30 tahun merupakan jumlah terbesar dibandingkan kelompok usia di bawah 15 tahun maupun di atas 30 tahun.

Ria Ricis memahami bahwa Ria Ricis secara status dan kepribadian adalah bagian dari milenial, maka Ria Ricis menetapkan target audiens yang memiliki kesamaan dengan dirinya yaitu milenial, khususnya milenial yang sangat menyukai dunia humor. Ria Ricis pun tahu sebagian besar orang yang aktif dalam media sosial memiliki tujuan hiburan sehingga tujuan dari Ria Ricis adalah untuk menghibur audiens dengan meme dan parodi video yang dibuat. Dengan begitu konten yang dibuat harus melibatkan pertimbangan bisa menarik minat dan menjawab kebutuhan milenial yakni ringan, lucu, dan up to date.

(3) Pemetaan media sosial yang digunakan, membangun personal branding harus juga memperhatikan saluran atau medium yang digunakan dalam membangun branding tersebut, karena setiap media sosial memiliki karakteristik yang berbeda, ada yang berfokus pada microblogging, audio, photo sharing, atau video. Setiap media sosial memiliki karakteristik audiens yang berbeda-beda pula. Jika salah menetapkan penggunaan media sosial maka personal branding bisa lama terbangunnya dengan kata lain tidak efisien.

Ria Ricis memahami persebaran target audiens yang dipilih adalah milenial yang aktif menggunakan Instagram dan YouTube, sehingga konten yang dibangun untuk memperkuat personal branding-nya adalah dengan menggunakan Instagram dan YouTube, dan tidak menggunakan Twitter, Podcast, dan lain-lain. Dengan dipilihnya Instagram dan YouTube maka konten yang harus disiapkan adalah foto dan video, dalam hal ini Ria Ricis membuat konten meme dan video parodi. Dari Instagram dan YouTube personal branding-nya terbangun hingga akhirnya ia ditawari untuk menjadi pembawa acara di televisi, kemudian ditawari bermain film. 


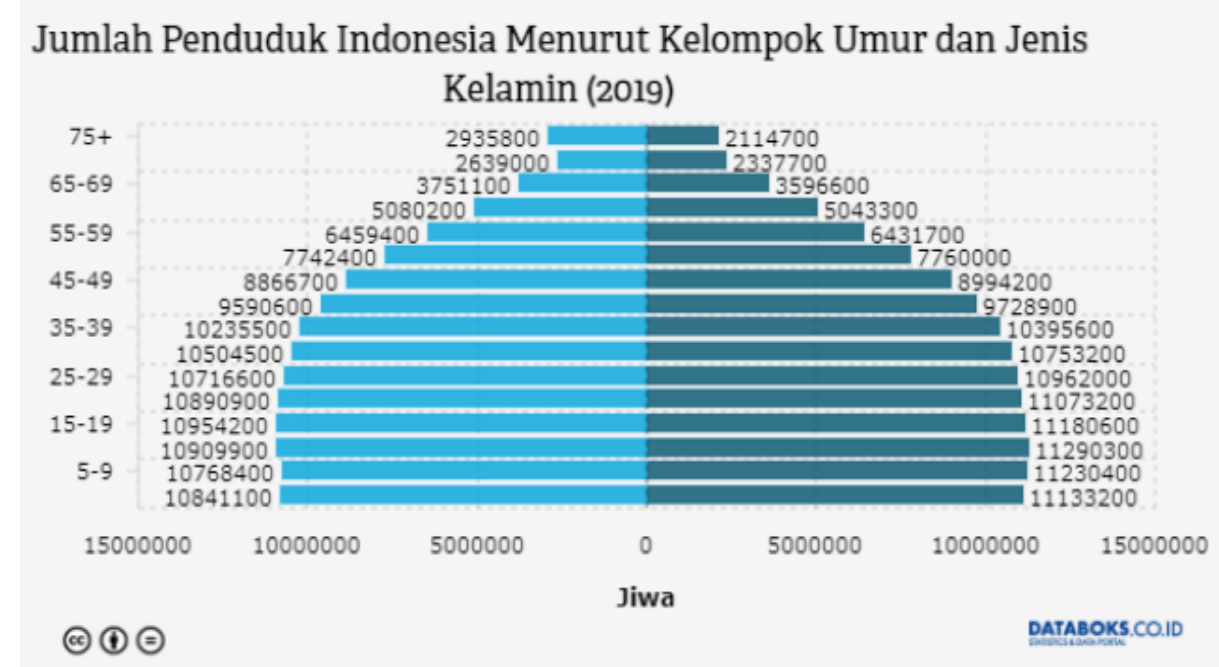

Sumber: Databoks.co.id (2019)

Gambar 7. Jumlah usia penduduk dan jenis kelamin

Pemetaan media sosial akan memengaruhi jenis konten yang tepat dan intensitas penerbitan konten yang akan disampaikan. Misalnya Instagram yang memiliki durasi video lebih pendek maka waktu untuk menayangkannya lebih fleksibel dan pada jam paling efektif di mana banyak orang mengaksesnya. Kemudian YouTube yang memiliki durasi video lebih panjang sehingga membutuhkan konten yang lebih menarik untuk memberikan daya tahan penontonnya. Hal ini sangat penting untuk membangun brand image usaha untuk melakukan repetisi agar tercipta konsistensi.

(4) Membangun

personal branding melalui media sosial, setelah mengetahui nilai apa, tagline apa, kepribadian, dan prestasi apa saja yang ingin ditampilkan untuk membangun personal branding maka selanjutnya yang harus dilakukan adalah mempersiapkan konten yang hendak dipublikasikan pada media sosial. Konten yang dipublikasikan harus sesuai dengan jenis media sosial yang digunakan. Jika YouTube maka mempersiapkan video-video, jika Instagram maka mempersiapkan foto dan video pendek yang merupakan keunggulan kompetitif seseorang, kekhasan, dan sesuatu yang bisa menjawab kebutuhan audiens. Apa yang diunggah harus dilakukan secara berulang/kontinu, hal ini untuk memperkuat personal branding yang konsisten.

Kepribadian Ria Ricis yang khas milenial, kocak, dan ceria harus mempersiapkan konten remaja yang menyukai video yang ringan, menjawab problematika remaja, kebutuhan hiburan tertawa dari rutinitas sekolah, dan lain-lain. Secara nyata Ria Ricis telah melakukannya dengan minimal membuat satu konten video YouTube dan mengunggah Instagram satu kali sehari. Tanpa konsistensi maka personal branding tidak akan terbangun dengan kuat.

\section{PENUTUP}

\section{Simpulan}

Dari keseluruhan artikel yang sudah dipelajari peneliti, maka simpulan strategi untuk membangun personal branding yang kuat pada media sosial adalah bahwa setidaknya ada beberapa langkah yang harus dilakukan seseorang, yaitu pemetaan diri, menetapkan target audiens, pemetaan media sosial yang dijadikan saluran komunikasi yang digunakan dan membangun personal branding di media sosial dengan konsisten.

Pemetaan diri digunakan untuk mengetahui keunggulan dan kelemahan diri, mana yang ingin ditampilkan kepada audiens dan mana yang tidak perlu ditampilkan. Pemetaan ini diperlukan untuk membangun identitas merk yang tepat.

Menetapkan target audiens untuk mengetahui dari heterogenitas audiens masalah audiens yang mana yang hendak diselesaikan. Subjek hendak memberikan manfaat dan nilai yang relevan pada 
kelompok audiens yang mana. Tentunya yang mampu dijangkau atau dipenuhi oleh kapasitas subjek. Sehingga subjek mampu membangun brand positioning yang jelas dan khas. Pemetaan saluran komunikasi akan mempengaruhi jenis konten dan intensitas waktu penayangan konten agar repetisi tercipta dan melahirkan konsistensi citra merk (brand image). Personal branding yang dilakukan oleh Ria Ricis sudah memenuhi strategi yang benar, dimulai dari Ria Ricis mampu memetakan keunggulan kompetitif sekaligus kekhasan yang ia miliki, target audiens yang disasar pun sesuai dengan kapasitas yang dimiliki dan besar jumlahnya. Kemudian saluran komunikasi yang digunakan yaitu media sosial pun tepat digunakan yakni Instagram dan YouTube di mana lebih dari $80 \%$ penduduk Indonesia menggunakannya. Tidak hanya ketepatan dalam memilih media komunikasinya, tetapi Ria Ricis pun mampu menggunakan media sosial Instagram dan YouTube itu dengan sangat baik hingga menghasilkan belasan juta follower dan belasan juta subscriber.

Adapun personal branding yang dilakukan Ria Ricis pun telah memenuhi unsur personal branding yang kuat karena memiliki nilai yang khas ada keunikan sekaligus pembeda dengan selainnya. Personal branding-nya memiliki relevansi dengan kebutuhan target audiensnya dan konsisten dibangun dengan menggunakan media sosial dengan konten-konten yang linier mencerminkan personal branding-nya.

\section{Saran}

Saran untuk penelitian selanjutnya adalah menggunakan perspektif audiens untuk menyimpulkan bagaimana persepsi yang akhirnya terbentuk dari pembangunan personal branding yang dilakukan oleh subjek tertentu. Idealnya penelitian ini mengombinasikan antara pendekatan kualitatif dan kuantitatif sehingga kita bisa melihat tidak hanya dari perspektif subjek yang melakukan personal branding pada media sosial, melainkan juga bisa melihat dari aspek objek audiens yang melihat aktivitas tersebut dan bagaimana hasil akhir dari branding yang terbentuk idealnya berdasarkan penilaian audiens. Sementara penelitian ini menyimpulkan adanya efektivitas dan efisiensi pembentukan personal branding dengan contoh Ria Ricis sebagai cara yang tepat hingga ia terkenal dengan sebutan selebgram berhijab yang kocak dengan melihat jumlah followers, subscribers serta aktivitas komentar atau interaksi dalam media sosial tersebut. Sejauh ini personal branding yang dilakukan Ria Ricis sudah khas (kocak, milenial), relevan (kebutuhan hiburan, komedi, sesuai dengan masalah milenial) dan konsisten (unggahan berkala baik di Instagram maupun di YouTube).

\section{DAFTAR PUSTAKA}

Asur, S. \& Huberman, B.A. (2010) Predicting the Future with Social Media. In: 2010 IEEE/WIC/ACM International Conference on Web Intelligence and Intelligent Agent Technology. [Online]. August 2010 IEEE. pp. 492-499. Available from: doi:10.1109/WI-IAT.2010.63.

Chaffey, D. \& Ellis-Chadwick, F. (2019) Digital Marketing: Strategy, Implementation, and Practice. 7th edition. New York, Pearson.

Denzin, N.K. \& Lincoln, Y.S. (2011) The SAGE Handbook of Qualitative Research. 4th edition. Norman K. Denzin \& Yvonna S. Lincoln (eds.). Sage Publications.

Fill (2013) CIM Coursebook Marketing Communications 07/08. [Online]. Routledge. Available from: doi:10.4324/9780080561103.

Hootsuite (2019) MOST ACTIVE SOCIAL MEDIA PLATFORMS. 2019. Hootsuite.

Instagram (2019) Instagram Riaricis1 795. 2019.

Katadata.co.id (2019) Berapa Pengguna Media Sosial Indonesia. [Online]. 2019. Available from:

https://databoks.katadata.co.id/datapublish/ 2019/02/08/berapa-pengguna-media-sosialindonesia.

Kotler, P. \& Pfoertsch, W. (2006) B2B Brand Management. Springer Berlin Heidelberg.

Kotler, P., Saunders, J., Armstrong, G. \& Wong, V. (1999) Principle of Marketing. 2nd edition. Prentice Hall Europe.

Labrecque, L.I., Markos, E. \& Milne, G.R. (2011) Online Personal Branding: Processes, Challenges, and Implications. Journal of Interactive Marketing. [Online] 25 (1), $37-$ 
50. Available from: doi:10.1016/j.intmar.2010.09.002.

McNally, D. \& Speak, K. (2010) Be Your Own Brand: Achieve More of What You Want by Being More of Who You Are. BerrettKoehler Publishers.

Montoya, P. \& Vandehey, T. (2002) The Personal Branding Phenomenon: Realize Greater Influence, Explosive Income Growth and Rapid Career Advancement by Applying the Branding Techniques of Michael, Martha \& Oprah. Peter Montoya Incorporated.

Munzi, A. (2019) Ria Ricis dapat Rp 400 Juta Sebulan, Raditya Dika Tergeser dan Sebut Ria Curang Karena Lakukan Ini. Bangkapos.com. [Online] Available from: https://bangka.tribunnews.com/2019/01/17/ ria-ricis-dapat-rp-400-juta-sebulan-radityadika-tergeser-dan-sebut-ria-curang-karenalakukan-ini.

Neuman, W.L. (2017) Metodologi Penelitian Sosial: Pendekatan Kualitatif dan Kuantitatif. 7th edition. Indeks.

Safko, L. \& Brake, D.K. (2009) The Social Media Bible: Tactics, Tools, and Strategies for Business Success. New Jersey, John Wiley and Sons, Inc.
Setiawan, T.S. (2019) Diminta Balik ke YouTube, Ria Ricis: Enggak Semudah Itu. Kompas.com. [Online] July. Available from:

https://sains.kompas.com/read/2019/07/28/ 183041310/diminta-balik-ke-youtube-riaricis-enggak-semudah-itu.

Tiago, M.T.P.M.B. \& Veríssimo, J.M.C. (2014) Digital marketing and social media: Why bother? Business Horizons. [Online] 57 (6), 703-708. Available from: doi:10.1016/j.bushor.2014.07.002.

TribunSumsel.com (2018) Berhenti jadi Polisi Pilih Jadi Artis Kemudian Jualan Bubur Tak Disangka Nasib Pria ini Sekarang. 2018. Tribunnews.

Yasmin, A., Tasneem, S. \& Fatema, K. (2015) Effectiveness of Digital Marketing in the Challenging Age: An Empirical Study. The International Journal of Management Science and Business Administration. [Online] 1 (5), 69-80. Available from: doi:10.18775/ijmsba.1849-56645419.2014.15.1006.

YouTube (2019) Ricis Official Youtube Channel. 2019. 